\title{
Geospatial variability in the autumn community structure of epipelagic zooplankton in the upper layer of the northern South China Sea
}

\author{
Li-Chun Tseng $^{1 \dagger}$, Hans-Uwe Dahms ${ }^{2 \dagger}$, Qing-Chao Chen ${ }^{3}$ and Jiang-Shiou Hwang ${ }^{1 *}$
}

\begin{abstract}
Background: For the present study, we collected mesozooplankton in the upper layer (above $100 \mathrm{~m}$ in depth) of four stations in the northern South China Sea (SCS) to determine the influence of different water masses on their distribution and abundance from 27 September to 2 October 1999.

Results: In total, 18 major zooplankton taxa were recovered from the samples. Calanoid copepods, Noctilucales, and chaetognaths were dominant and together comprised $65.90 \%$ of the overall zooplankton counts. Zooplankton densities ranged from 102.19 to 1,285.24 individuals per cubic meters (ind. $/ \mathrm{m}^{3}$ ) (average, $306.38 \pm 435.71$ ).

Noctilucales were abundant at stations located in the Kuroshio Current (KC) intrusion area. Integrating all samples, 32 copepod species were identified consisting of 23 genera belonging to 16 families. Total copepod abundances ranged from 30.24 to 311.17 ind. $/ \mathrm{m}^{3}$ (average, $99.14 \pm 97.84$ ). Numerically, Pleuromamma gracilis, Nannocalanus minor, and Lucicutia flavicornis were the most dominant species. The most frequently occurring species in all samples were Acartia (Acartia) negligens and Corycaeus (Farranula) gibbula. Results of a cluster analysis indicated that community structures of zooplankton and copepods of the northern SCS varied at geospatial scales during the sampling period.
\end{abstract}

Conclusions: Results of the present study suggest that the composition and community structure of zooplankton and copepods were influenced by intrusion of the KC in the shallow layer above $100 \mathrm{~m}$ in depth in the northern SCS. Some indicator species characteristic of the KC indicated that the study area received water masses from the northern SCS and the KC.

Keywords: Community structure; Zooplankton; Copepod; Upper layer; South China Sea

\section{Background}

Plankton plays important roles in transferring carbon and energy to upper consumer levels in aquatic ecosystems worldwide. Small single-cell phytoplankton contributes most to the primary production in open ocean ecosystems (Hwang et al. 2000b; Hwang and Martens 2011; Sanoamuang and Hwang 2011). Zooplankton consumes phytoplankton and plays important roles in transferring carbon and energy to upper trophic levels in the food web (Dahms et al. 2012). Planktonic copepods in turn are dominant taxa among zooplankton assemblages

\footnotetext{
* Correspondence: jshwang@mail.ntou.edu.tw

'Equal contributors

${ }^{1}$ Institute of Marine Biology, National Taiwan Ocean University, 2 Pei-Ning

Road, Keelung 20224, Taiwan

Full list of author information is available at the end of the article
}

(Tseng et al. 2008d, 2009; Chen et al. 2010; Hsiao et al. 2011; Chou et al. 2012). Their feeding behaviors deeply affect fluxes of carbon and energy (Chen et al. 2010; Vandromme et al. 2010; Wu et al. 2010, 2011). In this study, we examined the important issues of the distribution and community structure of zooplankton and planktonic copepods, which may provide useful information for understanding marine systems worldwide.

Previous reports studied zooplankton structures in the South China Sea (SCS): in northern areas (Chen 1992; Hwang et al. 2000a; Tseng et al. 2012b), coastal areas (Hwang et al. 2003; Tseng et al. 2008e), estuaries (Tan et al. 2004), and the Malacca Strait (Yoshida et al. 2006). The community structure of plankton is generally affected by the dynamics of water masses (Hwang et al. 2000a, 2007a; Tseng et al. 2012b) and the effects of 
monsoons (Hwang et al. 2004, 2006, 2009; Dur et al. 2007; Tseng et al. 2008c, 2011c; Dahms et al. 2012). Li et al. (2010) suggested that the SCS is the world's bestknown monsoonal climate zone. Seasonal monsoons play an important role in community alterations of copepods in waters around Taiwan (Hwang et al. 2004, 2006, 2009; Tseng et al. 2008c). Morton and Blackmore (2001) suggested that monsoon effects also cause seasonal changes in the zooplankton community structures in the SCS. Tseng et al. (2008a) and Chang et al. (2010) reported that copepod communities varied during the monsoon transition periods in the northern SCS. A few studies reported specific changes in autumn in surface waters of the subtropical SCS (Tseng et al. 2008a) and dynamic patterns in the northern SCS (Tseng et al. 2012a). In the northern SCS, most previous studies focused on copepod compositions in surface waters $(<10 \mathrm{~m})$ (Lo et al. 2001, 2004b; Tseng et al. 2008e, 2012b; Chang et al. 2010). Mesozooplankton studies were conducted in the northern SCS at different depths, ranging 2 to 4,500 $\mathrm{m}$ (Hwang et al. 2007a), 0 to $150 \mathrm{~m}$ (Hwang et al. 2007b, 2010), and 0 to $300 \mathrm{~m}$ (Tseng et al. 2008a). However, copepod communities in shallower waters $(<100 \mathrm{~m})$ have not been investigated before in the northern SCS.

The SCS is as yet a poorly studied region in terms of the roles zooplankton and planktonic copepods assume in autumn. Morton and Blackmore (2001) suggested that the SCS is probably the world's most diverse marine region. Hydrographic data and measurements of both chemical and biological variables in the SCS are rare (Pauly and Christensen 1993). An investigation of the effects of biogeochemical processes on oceanographic events was initiated during the South East Asia Time Series (SEATS) study (Ding et al. 2004). The present study is the first to reveal zooplankton communities in waters shallower than $100 \mathrm{~m}$ in the northern SCS. The objectives of the present study were to understand (1) the community structure of zooplankton and (2) the distribution and assemblages of planktonic copepods in shallow waters (above $100 \mathrm{~m}$ in depth) of the northern SCS during the advent of the northeastern monsoonal wind regime.

\section{Methods}

\section{Field sampling, identification, and enumeration}

For the present study, zooplankton was sampled in the northern SCS during cruise 563 of the Ocean Research Vessel III from 27 September to 2 October 1999. Locations and details of the sampling stations are provided in Table 1 and Figure 1. A transect line with four stations was chosen from southwestern Taiwan to the southernmost SEATS station. Zooplankton samples were collected by oblique tows with a standard North Pacific zooplankton net (with a mouth diameter of $45 \mathrm{~cm}$ and a mesh size of $333 \mu \mathrm{m})$ from $100 \mathrm{~m}$ in depth to the surface at each station. A flow meter (Hydro bios, Kiel, Germany) was attached in the center of the net opening for later estimation of the seawater volume filtered. In addition, zooplankton samples were taken every $5 \mathrm{~h}$ at the SEATS station to elucidate the diurnal dynamics of the assemblages (Table 1). After retrieval from the ocean, the zooplankton samples were immediately preserved in seawater with a 5\% formalin solution for further enumeration and identification. Prior to plankton collection, a conductivitytemperature-depth instrument (Sea-Bird Electronics, Inc., Bellevue, WA, USA) was used to obtain information on temperature $(T)$ and salinity $(S)$ from the area where zooplankton tows were subsequently taken.

In the laboratory, samples were split with a Folsom splitter until the subsample contained fewer than 500 specimens. Zooplankton and copepods were sorted and identified to species level using the identification aids of Chen and Zhang (1965), Chen and Shen (1974), and Chen et al. (1974). Additional original papers were used for species identification when required.

\section{Statistical analyses}

Species density matrices were analyzed using multivariate analyses for copepod species. Significance levels of Bray-Curtis similarity among stations of copepod assemblages were calculated using the computer program, Paleontological Statistics (Hammer et al. 2001). The abundance of all copepod species in each sample was used to calculate similarities before clustering. The functional test of Box and Cox (1964) for transforming data was applied before similarity analysis. The value $(\lambda)$ of the power transformation was 0.84 , and then the copepod densities of all samples were transformed as $\log (x+1)$. Indicator copepod species among each cluster were identified using the value index (IndVal) (Dufrêne and Legendre 1997). In the present study, we only calculated values of

\begin{tabular}{|c|c|c|c|c|c|}
\hline \multirow[t]{2}{*}{ Station } & \multirow{2}{*}{$\begin{array}{l}\text { Depth } \\
\text { (m) }\end{array}$} & \multicolumn{2}{|c|}{ Location of station } & \multirow[t]{2}{*}{ Date } & \multirow{2}{*}{$\begin{array}{l}\text { Time } \\
\text { (hours) }\end{array}$} \\
\hline & & $\begin{array}{l}\text { Longitude } \\
\text { (E) }\end{array}$ & $\begin{array}{l}\text { Latitude } \\
\text { (N) }\end{array}$ & & \\
\hline$\overline{\mathrm{A} 1}$ & 1,500 & $119^{\circ} 30.043^{\prime}$ & $21^{\circ} 50.076^{\prime}$ & 1 October 1999 & 0630 \\
\hline $\mathrm{A} 2$ & 2,600 & $118^{\circ} 52.544^{\prime}$ & $21^{\circ} 07.045^{\prime}$ & 1 October 1999 & 0030 \\
\hline A3 & 2,650 & $118^{\circ} 11.031^{\prime}$ & $20^{\circ} 20.167^{\prime}$ & $\begin{array}{l}30 \text { September } \\
1999\end{array}$ & 1830 \\
\hline \multirow[t]{4}{*}{ SEATS } & 3,750 & $115^{\circ} 28.558^{\prime}$ & $18^{\circ} 00.957^{\prime}$ & 29 September & 0800 \\
\hline & & & & & 1300 \\
\hline & & & & & 1800 \\
\hline & & & & & 2300 \\
\hline
\end{tabular}

Sampling was done on 27 September to 2 October 1999. 


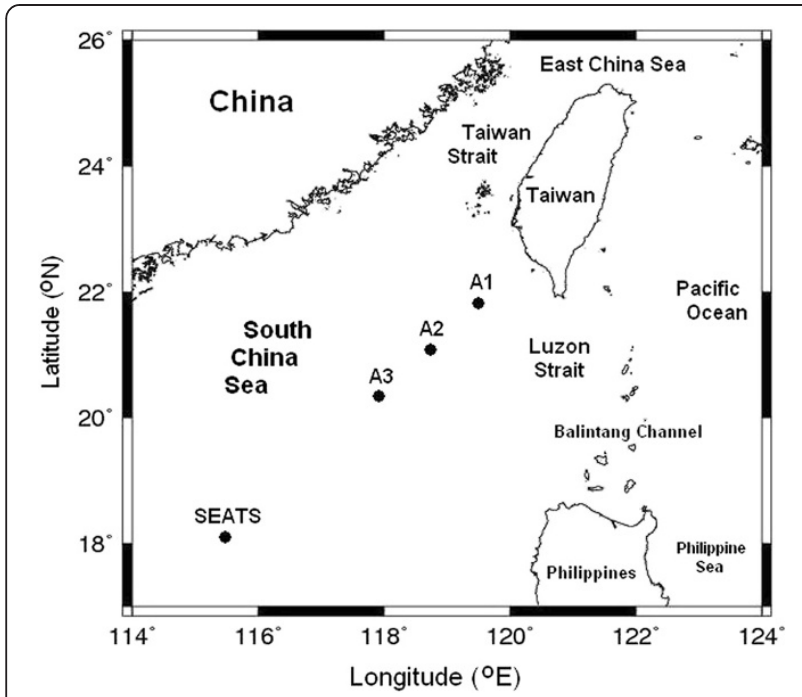

Figure 1 Map of sampling stations of cruise ORIII-CR 563 on 27 September to 2 October 1999.

the IndVal for copepod species with relative abundances of $>5 \%$ in each cluster grouping. The ShannonWiener diversity index was used to evaluate species diversity, while the Margalef richness index and Pielou's evenness were used to estimate the copepod community composition in each sample. Student's $t$ test was used to compare mean values of copepod abundance, species richness, and indices between samples collected from the SEATS stations in the northern SCS.

\section{Results and discussion \\ Results \\ Hydrographic information}

Satellite images of monthly average sea surface temperatures, provided by the National Oceanic and Atmospheric Administration, showed that surface values exceeded $28^{\circ} \mathrm{C}$ in the northern SCS in September 1999 (Figure 2). Vertical profiles of temperature and salinity above a depth of $120 \mathrm{~m}$ are shown for all sampling stations (Figure 3).

Temperature profiles demonstrated that surface waters in a layer above $40 \mathrm{~m}$ in depth were about $28^{\circ} \mathrm{C}$ without a clear difference between sampling stations. The depth of the thermocline was at about $40 \mathrm{~m}$. The temperature decreased with depth in a vertical profile from 40 to $120 \mathrm{~m}$. The temperature of waters below $40 \mathrm{~m}$ in depth clearly varied between stations. Temperatures were higher at the northern stations than at the SEATS stations (Figure 3A). Salinities showed a contrasting trend to temperature. The salinity at the surface was about 33.6 at stations A1 and A2 and was slightly lower at about 33.2 at stations A3 and SEATS. Salinities showed a clearly increasing trend from the surface to $120 \mathrm{~m}$ deep at each sampling station (Figure 3B). Vertical T-S profiles are shown for each station in Figure $3 \mathrm{C}$. The reference $T-S$ curves demarcate characteristics of the waters in the Kuroshio Current (KC) area $\left(21.419^{\circ} \mathrm{N}, 122.333^{\circ} \mathrm{E}\right)$ above $250 \mathrm{~m}$ recorded from a cruise in October 2001. T-S curves indicated that the water masses at the northern stations $\mathrm{A} 1$ and $\mathrm{A} 2$ were characterized by high temperatures and salinities. The water properties (Figure $3 \mathrm{C}$ ) of stations $\mathrm{A} 1$ and $\mathrm{A} 2$ showed similarities to those of the KC. In contrast, the
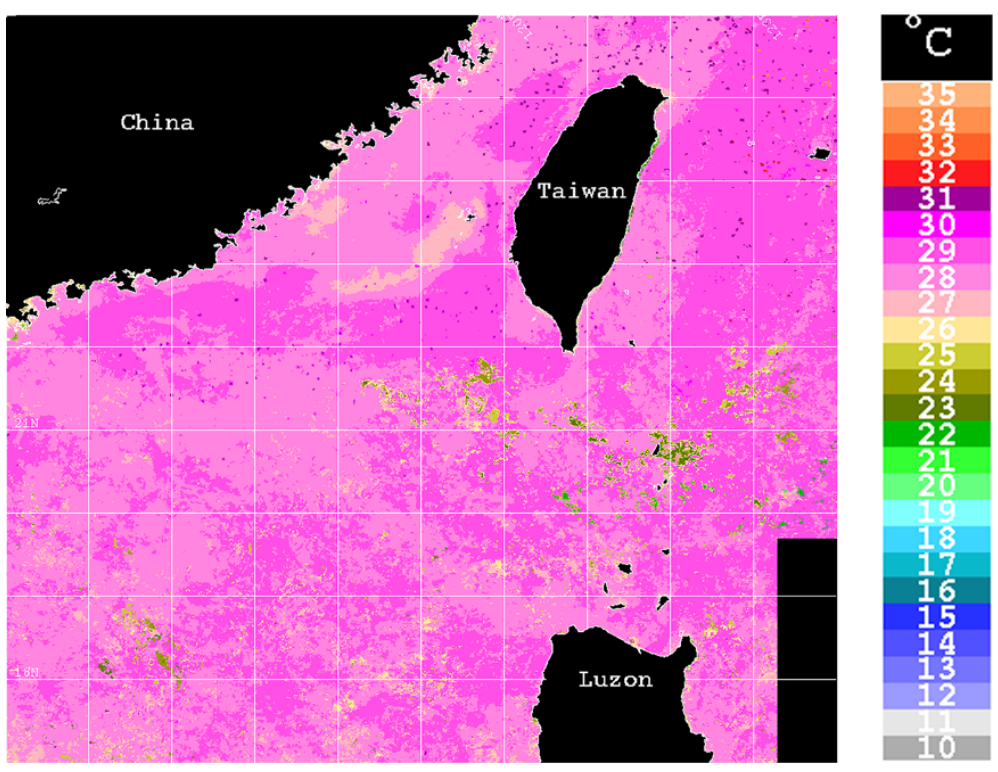

Figure 2 Satellite image showing monthly averaged information of surface seawater temperatures in September 1999. 

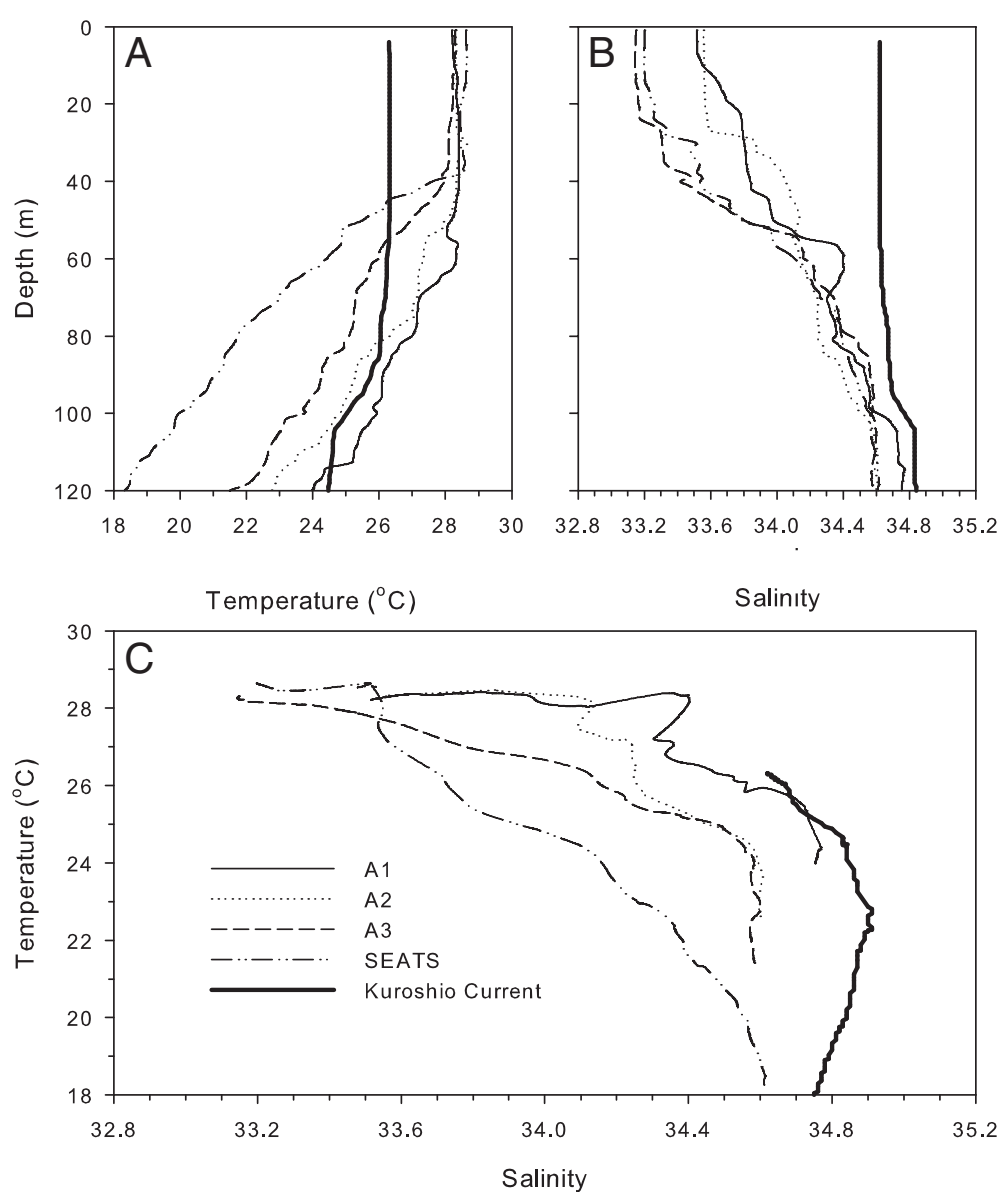

Figure 3 Variations in temperature (T), salinity (S), and $\boldsymbol{T}$ vs. S. (A) Temperature (T), (B) salinity (S), and (C) T vs. S in the zone above $120 \mathrm{~m}$ deep at each sampling station. The solid bold lines of the $T$-S curves represent the Kuroshio water $\left(21.419^{\circ} \mathrm{N}, 122.333^{\circ} \mathrm{E}\right)$ recorded from a cruise on 12 to 23 October 2001

SEATS station was characterized by low temperatures and salinities of the SCS water. The water at station A3 showed mixed characteristics of the $\mathrm{KC}$ and SEATS (Figure 3C).

\section{Zooplankton composition and abundance}

We identified 18 zooplankton taxa from all samples (Table 2). Comparing the zooplankton from all samples, the ranking by abundance of dominant taxa was as follows: calanoid copepods (relative abundance (RA) of $26.51 \%$ ), Noctilucales (Dinophyceae) (RA of 23.79\%), chaetognaths (RA of $15.60 \%$ ), ostracods (RA of $10.11 \%$ ), Foraminifera (RA of $6.95 \%$ ), and poecilostomatoid copepods (RA of $4.40 \%$ ). The top three dominant taxa (calanoid copepods, Noctilucales, and chaetognaths) together comprised $65.90 \%$ of the overall zooplankton counts (Table 2). Figure 4 shows variations in the total abundances and taxon numbers of zooplankton (Figure 4A) and their proportions (Figure 4B) at each sampling station. Results of neither abundance nor number of zooplankton taxa showed a clear pattern among samples. Zooplankton densities ranged from 102.19 individuals per cubic meters (ind. $/ \mathrm{m}^{3}$ ) (station SEATS, 0800 hours) to1,285.24 ind. $/ \mathrm{m}^{3}$ (station A2) with an average of $306.38 \pm 435.71$ ind. $/ \mathrm{m}^{3}$. Station A2 showed the highest densities of zooplankton. Samples were collected after midnight (0030 hours) there. The number of zooplankton taxa at each station ranged between 13 (station SEATS at 2300 hours) and 17 per station (station A3), averaging $14.71 \pm 1.50$ per station (Figure 4A). Variations in abundances and numbers of zooplankton taxa showed no significant correlation ( $r=0.04, p=0.932$, Pearson's correlation) among seven samples.

Zooplankton compositions varied among all samples. The composition of the top six dominant zooplankton taxa is shown in Figure 4B. Considering all zooplankton taxa and samples, calanoid copepods were the most dominant taxon, ranging from $19.91 \%$ (station A1) to $52.11 \%$ (SEATS station at 1800 hours). Noctilucales showed higher RA values at stations A1 A3, ranging from $19.60 \%$ (station A3) to $59.00 \%$ (station A1). Noctilucales were abundant at stations located in the $\mathrm{KC}$ intrusion area 
Table 2 Mean abundance, relative abundance, and occurrence ratio of each zooplankton taxon

\begin{tabular}{|c|c|c|c|}
\hline Zooplankton taxa & $\begin{array}{l}\text { Mean } \pm \text { SD } \\
\text { (ind. } / \mathrm{m}^{3} \text { ) }\end{array}$ & RA (\%) & OR (\%) \\
\hline \multicolumn{4}{|l|}{ Dinophyta/Dinophyceae } \\
\hline Noctiluca spp. & $72.89 \pm 139.95$ & 23.79 & 85.71 \\
\hline \multicolumn{4}{|l|}{$\begin{array}{l}\text { Protozoa/Sarcomastigophora/ } \\
\text { Radiolaria }\end{array}$} \\
\hline Radiolaria & $3.12 \pm 4.94$ & 1.02 & 57.14 \\
\hline \multicolumn{4}{|l|}{$\begin{array}{l}\text { Chromista/Harosa/Rhizaria/ } \\
\text { Foraminifera }\end{array}$} \\
\hline Foraminifera & $21.28 \pm 50.31$ & 6.95 & 85.71 \\
\hline \multicolumn{4}{|l|}{$\begin{array}{l}\text { Animalia/Eumetazoa/ } \\
\text { Coelenterata }\end{array}$} \\
\hline Medusa & $6.26 \pm 9.28$ & 2.04 & 100.0 \\
\hline \multicolumn{4}{|l|}{ Annelida/Polychaeta } \\
\hline Polychaeta & $2.01 \pm 3.12$ & 0.66 & 85.71 \\
\hline \multicolumn{4}{|l|}{$\begin{array}{l}\text { Chaetognatha/Sagittidea/ } \\
\text { Sagittidae }\end{array}$} \\
\hline Sagitta spp. & $47.8 \pm 53.62$ & 15.60 & 100.0 \\
\hline \multicolumn{4}{|l|}{$\begin{array}{l}\text { Arthropoda/Crustacea/ } \\
\text { Branchiopoda }\end{array}$} \\
\hline Ostracoda & $30.99 \pm 71.88$ & 10.11 & 100.0 \\
\hline \multicolumn{4}{|l|}{$\begin{array}{l}\text { Arthropoda/Crustacea/ } \\
\text { Copepoda }\end{array}$} \\
\hline Calanoida & $81.23 \pm 93.13$ & 26.51 & 100.0 \\
\hline Cyclopoida & $3.7 \pm 8.92$ & 1.21 & 28.57 \\
\hline Harpacticoida & $0.71 \pm 1.37$ & 0.23 & 42.86 \\
\hline Poecilostomatoida & $13.49 \pm 7.58$ & 4.40 & 100.0 \\
\hline \multicolumn{4}{|l|}{$\begin{array}{l}\text { Arthropoda/Crustacea/ } \\
\text { Malacostraca }\end{array}$} \\
\hline Amphipoda & $1.25 \pm 1.54$ & 0.41 & 71.43 \\
\hline Lucifera larvae & $4.78 \pm 4.59$ & 1.56 & 100.0 \\
\hline Euphausiacea & $6.98 \pm 12.91$ & 2.28 & 100.0 \\
\hline \multicolumn{4}{|l|}{ Animalia/Mollusca } \\
\hline Pteropoda & $1.97 \pm 3.26$ & 0.64 & 71.43 \\
\hline \multicolumn{4}{|l|}{ Protochordata/Urochordata } \\
\hline Appendicularia & $1.22 \pm 1.54$ & 0.40 & 71.43 \\
\hline \multicolumn{4}{|l|}{$\begin{array}{l}\text { Protochordata/Urochordata/ } \\
\text { Thaliacea }\end{array}$} \\
\hline Thaliacea & $4.83 \pm 7.91$ & 1.58 & 85.71 \\
\hline \multicolumn{4}{|l|}{$\begin{array}{l}\text { Eumetazoa/Deuterostomia/ } \\
\text { Chordata }\end{array}$} \\
\hline Fish larvae & $1.87 \pm 3.2$ & 0.61 & 85.71 \\
\hline
\end{tabular}

Mean abundance (mean \pm standard deviation, individuals per cubic meters (ind. $\left./ \mathrm{m}^{3}\right)$ ), relative abundance (RA), and occurrence ratio (OR) of each zooplankton taxon during the cruise ORIII-CR 563 on 27 September to 2 October 1999.

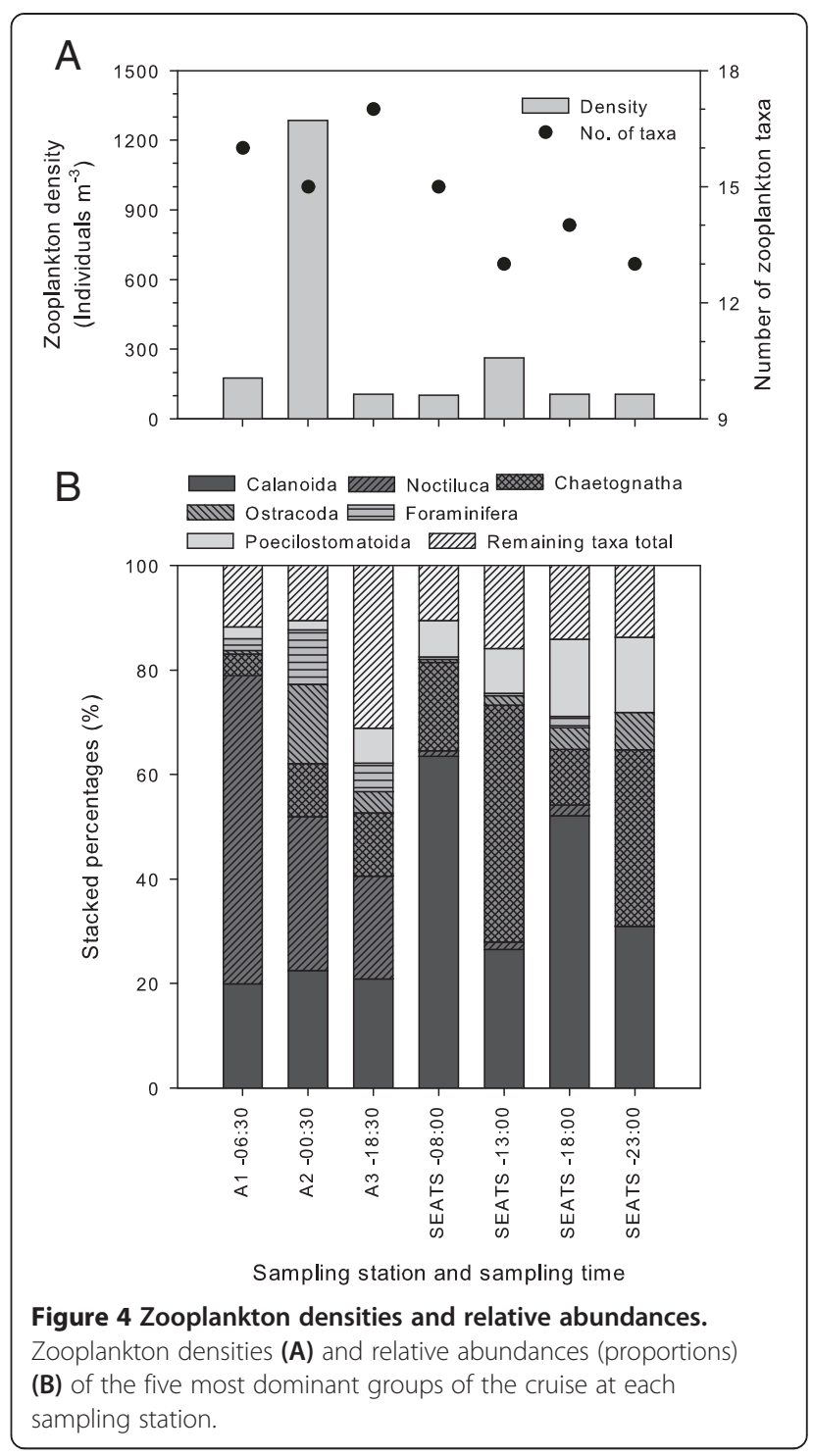

(stations A1 to A3) but low in the area of the SEATS station. Chaetognaths had a high proportion of $45.35 \%$ (SEATS station at 1300 hours), and ostracods were abundant at station A2 (15.09\%). Foraminifera and poecilostomatoid copepods respectively showed high proportions of $10.53 \%$ in samples from station A2 and $14.79 \%$ at the SEATS station (at 1300 hours) (Figure 4B). Among the top six most abundant zooplankton taxa, RA values of Noctilucales in samples of stations A1 to A3 were significantly higher than those in samples at the SEATS station $(t=3.52, p=0.017$, Student's $t$ test). On the contrary, RA values of poecilostomatoid copepods in samples of stations A1 to A3 were lower than those of samples collected from the SEATS station $(t=-2.817, p=$ 0.037 , Student's $t$ test). These results demonstrated substantial geospatial variability in the community structure and distribution of zooplankton. 


\section{Copepod abundance and diversity}

From the six samples, we identified 32 copepod species (including five species which were solely identified to the generic level). These copepods belonged to 4 orders, 16 families, and 23 genera (Table 3). Figure 5 shows variations in copepod abundances, species numbers (Figure 5A), indices of richness, diversity, evenness (Figure 5B), and relative abundances of the four copepod orders (Figure 5C) at each sampling station. Copepod total abundances ranged from 30.24 ind. $/ \mathrm{m}^{3}$ (station A3) to 311.17 ind./ $\mathrm{m}^{3}$ (station A2), with a mean of $99.14 \pm 97.84$ ind. $/ \mathrm{m}^{3}$. Variations in zooplankton abundances showed a similar trend to copepod abundances among sampling stations (Figure 4A). The highest copepod density was recorded at station $\mathrm{A} 2$ with a sampling time of just after midnight (0030 hours). Numbers of copepod species identified at each station ranged from 11 (stations A1 and A2) to 19 (SEATS station at 0800 and 1800 hours), with a mean of $15.29 \pm 3.35$ species per station (Figure $5 \mathrm{~A}$ ).

Indices of copepod species richness, Shannon-Wiener diversity, and evenness differed among stations (Figure 5B). The richness index of each sample ranged from 1.74 (station A2) to 4.69 (station A3), with an average value of $3.44 \pm 1.03$. The Shannon-Wiener diversity index ranged from 1.83 (station A2) to 2.54 (station A3), with a mean value of $2.29 \pm 0.28$. The evenness index of each sample ranged from 0.76 (station A2) to 0.92 (SEATS station at 2300 hours), with a mean of $0.84 \pm 0.06$ (Figure 5B).

Proportions of the four copepod orders in each sample are shown in Figure 5B. Calanoid copepods were most abundant in most samples. Proportions of calanoid copepods ranged from $60.0 \%$ (SEATS station at 1300 hours) to 92.75\% (station A2), followed by poecilostomatoid and cyclopoid copepods, with the lowest proportion for harpacticoid copepods. Poecilostomatoid and cyclopoid copepods showed the highest proportions of $31.76 \%$ at the SEATS station at 2300 hours and $20.51 \%$ at 1300 hours, respectively. Harpacticoid copepods showed the lowest abundance among all samples. Compositions of the different copepod orders collected from seven samples substantially varied (Figure $5 \mathrm{C}$ ).

Of all the samples, the top five abundant species were Pleuromamma gracilis (Claus, 1863) (RA of 18.54\%), Nannocalanus minor (Claus, 1863) (RA of 10.07\%), Lucicutia flavicornis (Claus, 1863) (RA of 9.31\%), Acartia (Acartia) negligens Dana, 1849 (RA of 8.95\%), and Clausocalanus arcuicornis (Dana, 1849) (RA of 8.95\%). The total number of the top five most abundant species represented $55.82 \%$ of the total abundance of all samples (Table 3). The most common copepod species in the present study were $A$. (A.) negligens and Corycaeus (Farranula) gibbula Giesbrecht, 1891, both of which had a $100 \%$ occurrence rate (OR), followed by $C$. arcuicornis, Cosmocalanus darwini (Lubbock, 1860) and
Oncaea venusta Philippi, 1843 with an OR of $85.74 \%$ (Table 3).

\section{Copepod communities and distribution}

The ordination dendrogram shows results of the clustering analysis that calculated similarity distances among samples by the Bray-Curtis method (Figure 6), which revealed similarities of copepod communities among all samples during the sampling period. IndVal values of copepods that had a relative abundance of $>5 \%$ in each cluster group were calculated and are shown in Table 4.

The sample collected from station A2 showed the highest abundance, whereas the lowest values of richness, diversity, and evenness indices (Figure 5A) were separated from the others and allocated to group IA. The top three dominant copepod species of group IA were $P$. gracilis (36.23\%), $N$. minor (20.29\%), and $L$. flavicornis (18.84\%) (Table 4). At the next grouping level, all samples collected from the SEATS station were placed into group IIA, which showed high richness and diversity indices (Figure 5B) and a particular composition of copepod species. The top three dominant species of group IIA were C. arcuicornis (16.03\%), C. (F.) gibbula (13.37\%), and $A$. (A.) negligens (11.60\%). The remaining two samples of A1 and A3 were placed into group IIB, and the most dominant species of group IIB were $A$. (A.) negligens (24.12\%), C. arcuicornis (17.08\%), and Paracalanus spp. (8.93\%). Differences within each group are shown in the results of IndVal values (Table 4). Results of the present study suggested that copepod communities at depths of $<100 \mathrm{~m}$ in the northern SCS were influenced by the water characteristics (Figure 3) and varied spatially in the horizontal dimension (Figure 1) during the sampling period.

\section{Copepod communities at the SEATS station}

Cluster analysis results (Figure 6) indicated that copepod communities at the SEATS station differed from samples collected from the northern SCS (stations A1 to A3). Results of a rank abundance (\%) analysis of planktonic copepod species sampled from the SEATS station in the northern SCS in autumn 1999 are given in Figure 7. Patterns of rank abundance curves were relatively similar among the four samples. Among samples at the SEATS station, two samples collected at 0800 and 1800 hours had higher species numbers than the other samples. The SEATS station recorded 31 copepod species in total from four vertical samples (water column samples from $100 \mathrm{~m}$ to the surface). Among all samples from the entire cruise, $96.9 \%$ of copepod species were identified at the SEATS station, and 10 species were only found in samples from the SEATS station (Table 5). The highest density was found for C. arcuicornis (12.57 \pm 7.75 ind. $\left./ \mathrm{m}^{3}\right)$, and the lowest densities were found for Euchaeta indica Wolfenden, 1905, 
Table 3 Mean abundance, relative abundance, and occurrence ratio of each copepod species

\begin{tabular}{|c|c|c|c|}
\hline Species name & $\begin{array}{l}\text { Mean } \pm \text { SD } \\
\text { (ind. } / \mathrm{m}^{3} \text { ) }\end{array}$ & RA (\%) & OR (\%) \\
\hline \multicolumn{4}{|l|}{ Calanoida } \\
\hline \multicolumn{4}{|l|}{ Acartiidae } \\
\hline $\begin{array}{l}\text { Acartia (Acartia) negligens Dana, } \\
1849\end{array}$ & $8.87 \pm 5.82$ & 8.95 & 100.0 \\
\hline $\begin{array}{l}\text { Canthocalanus pauper } \\
\text { (Giesbrecht, 1888) }\end{array}$ & $1.61 \pm 1.66$ & 1.62 & 71.43 \\
\hline $\begin{array}{l}\text { Cosmocalanus darwini (Lubbock, } \\
\text { 1860) }\end{array}$ & $3.63 \pm 6.41$ & 3.66 & 85.71 \\
\hline Undinula vulgaris (Dana, 1849) & $1.16 \pm 1.85$ & 1.17 & 42.86 \\
\hline Nannocalanus minor (Claus, 1863) & $9.98 \pm 23.46$ & 10.07 & 57.14 \\
\hline Neocalanus gracilis (Dana, 1849) & $1.07 \pm 1.62$ & 1.08 & 57.14 \\
\hline \multicolumn{4}{|l|}{ Calocalanidae } \\
\hline Calocalanus spp. & $1.01 \pm 1.57$ & 1.02 & 42.86 \\
\hline \multicolumn{4}{|l|}{ Candaciidae } \\
\hline $\begin{array}{l}\text { Paracandacia truncata (Dana, } \\
\text { 1849) }\end{array}$ & $1.39 \pm 1.81$ & 1.40 & 57.14 \\
\hline \multicolumn{4}{|l|}{ Centropagidae } \\
\hline $\begin{array}{l}\text { Centropages calaninus (Dana, } \\
\text { 1849) }\end{array}$ & $0.42 \pm 0.82$ & 0.42 & 28.57 \\
\hline \multicolumn{4}{|l|}{ Clausocalanidae } \\
\hline $\begin{array}{l}\text { Clausocalanus arcuicornis (Dana, } \\
\text { 1849) }\end{array}$ & $8.87 \pm 7.46$ & 8.95 & 85.71 \\
\hline $\begin{array}{l}\text { Clausocalanus furcatus (Brady, } \\
\text { 1883) }\end{array}$ & $2.28 \pm 3.74$ & 2.30 & 57.14 \\
\hline $\begin{array}{l}\text { Clausocalanus mastigophorus } \\
\text { (Claus, 1863) }\end{array}$ & $5.25 \pm 5.11$ & 5.30 & 71.43 \\
\hline \multicolumn{4}{|l|}{ Eucalanidae } \\
\hline $\begin{array}{l}\text { Pareucalanus attenuatus (Dana, } \\
\text { 1849) }\end{array}$ & $0.4 \pm 0.78$ & 0.40 & 28.57 \\
\hline $\begin{array}{l}\text { Subeucalanus subcrassus } \\
\text { (Giesbrecht, 1888) }\end{array}$ & $0.96 \pm 1.66$ & 0.97 & 42.86 \\
\hline $\begin{array}{l}\text { Subeucalanus subtenuis } \\
\text { (Giesbrecht, 1888) }\end{array}$ & $2.97 \pm 2.75$ & 3.00 & 71.43 \\
\hline \multicolumn{4}{|l|}{ Euchaetidae } \\
\hline Euchaeta indica Wolfenden, 1905 & $0.07 \pm 0.19$ & 0.07 & 14.29 \\
\hline \multicolumn{4}{|l|}{ Lucicutiidae } \\
\hline Lucicutia flavicornis (Claus, 1863) & $9.23 \pm 21.85$ & 9.31 & 42.86 \\
\hline \multicolumn{4}{|l|}{ Metridinidae } \\
\hline $\begin{array}{l}\text { Pleuromamma gracilis (Claus, } \\
\text { 1863) }\end{array}$ & $18.38 \pm 41.74$ & 18.54 & 57.14 \\
\hline \multicolumn{4}{|l|}{ Paracalanidae } \\
\hline $\begin{array}{l}\text { Acrocalanus gracilis Giesbrecht, } \\
1888\end{array}$ & $0.24 \pm 0.46$ & 0.24 & 28.57 \\
\hline Paracalanus spp. & $0.88 \pm 1.51$ & 0.89 & 28.57 \\
\hline \multicolumn{4}{|l|}{ Temoridae } \\
\hline $\begin{array}{l}\text { Temora discaudata (Giesbrecht, } \\
\text { 1889) }\end{array}$ & $2.48 \pm 4.9$ & 2.50 & 71.43 \\
\hline Temora turbinata (Dana, 1849) & $0.07 \pm 0.19$ & 0.07 & 14.29 \\
\hline
\end{tabular}

Table 3 Mean abundance, relative abundance, and occurrence ratio of each copepod species (Continued)

Cyclopoida

Oithonidae

Oithona spp.

$3.7 \pm 8.92 \quad 3.73$

28.57

Harpacticoida

Ectinosomatidae

Microsetella norvegica (Boeck, 1846)

Miraciidae

Macrosetella gracilis (Dana, 1847)

$0.18 \pm 0.31$

0.18

28.57

Poecilostomatoida

Corycaeidae

Corycaeus spp.

$0.11 \pm 0.28 \quad 0.11 \quad 14.29$

Corycaeus (Farranula) concinna

(Dana, 1847)

Corycaeus (Farranula) gibbula

Giesbrecht, 1891

Corycaeus (Onychocorycaeus)

agilis Dana, 1849

Oncaeidae

Oncaea mediterranea Claus, $1861 \quad 1.49 \pm 2.59 \quad 1.50 \quad 42.86$

Oncaea spp.

$0.11 \pm 0.28 \quad 0.11 \quad 14.29$

Oncaea venusta Philippi, 1843

$3.42 \pm 4.54$

$3.45 \quad 85.71$

Mean abundance (mean \pm standard deviation, individuals per cubic meters (ind. $\left./ \mathrm{m}^{3}\right)$ ), relative abundance (RA), and occurrence ratio (OR) of each copepod species during the cruise ORIII-CR 563 on 27 September to 2 October 1999.

Temora turbinata (Dana, 1849), and Macrosetella gracilis (Dana, 1847) $\left(0.13 \pm 0.26\right.$ ind. $\left./ \mathrm{m}^{3}\right)$ at the SEATS station.

\section{Discussion}

Zooplankton composition and abundance

Irigoien et al. (2002) reported that crustacean zooplankters are key organisms in aquatic ecosystems because they represent an important link in marine food webs. They transport materials and energy from the primary production of phytoplankton to higher-level consumers, i.e., many fish species, in the oceans. In the present study, the RA value of total crustaceans was $46.71 \%$ (Table 2) if only the proportion of crustacean abundance among all mesozooplankton was considered. After removing the protist taxa (the Noctilucales, Radiolaria, and Foraminifera) from the records of this study, the proportion of total crustaceans increased their dominance to an RA of $65.57 \%$. The present results also confirmed for the SCS that Irigoien et al. (2002) suggested about the crustacean zooplankton being abundant and important in waters above $100 \mathrm{~m}$ in depth in the northern SCS.

Only a few investigations have examined zooplankton assemblages in waters of the SCS so far. Previous reports 


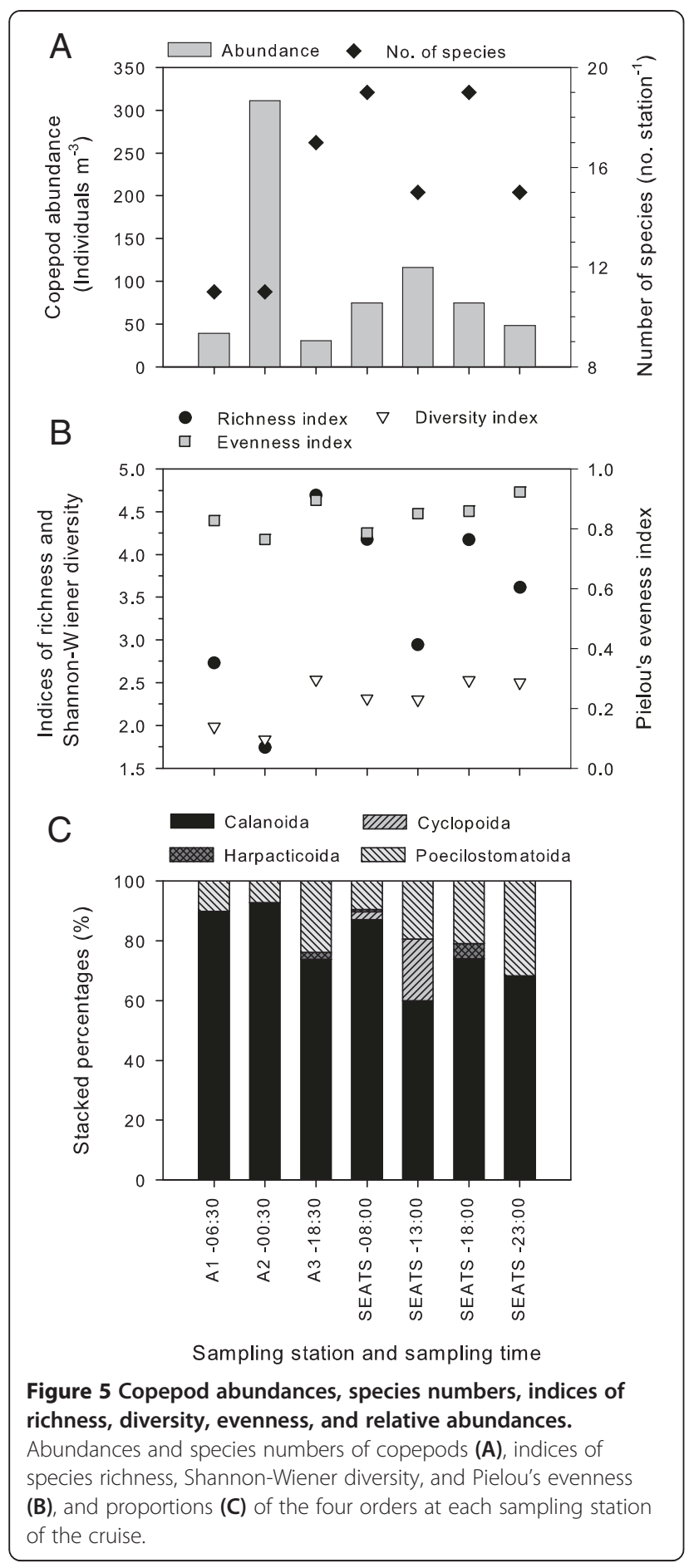

analyzed the zooplankton community in coastal areas of urban outfalls in the northern SCS (Tseng et al. 2008e) and of surface waters of the northern SCS (Tseng et al. 2012b). Calanoid copepods represent the most abundant taxon in waters of southwestern Taiwan $(125.71 \pm 108.36$ ind. $/ \mathrm{m}^{3}$, RA of $37.03 \%$; Tseng et al. 2008b) and the second most abundant taxon in the northern SCS (300.55 \pm 187.01 ind. $/ \mathrm{m}^{3}$, RA of $21.75 \%$; Tseng et al. 2012b). The

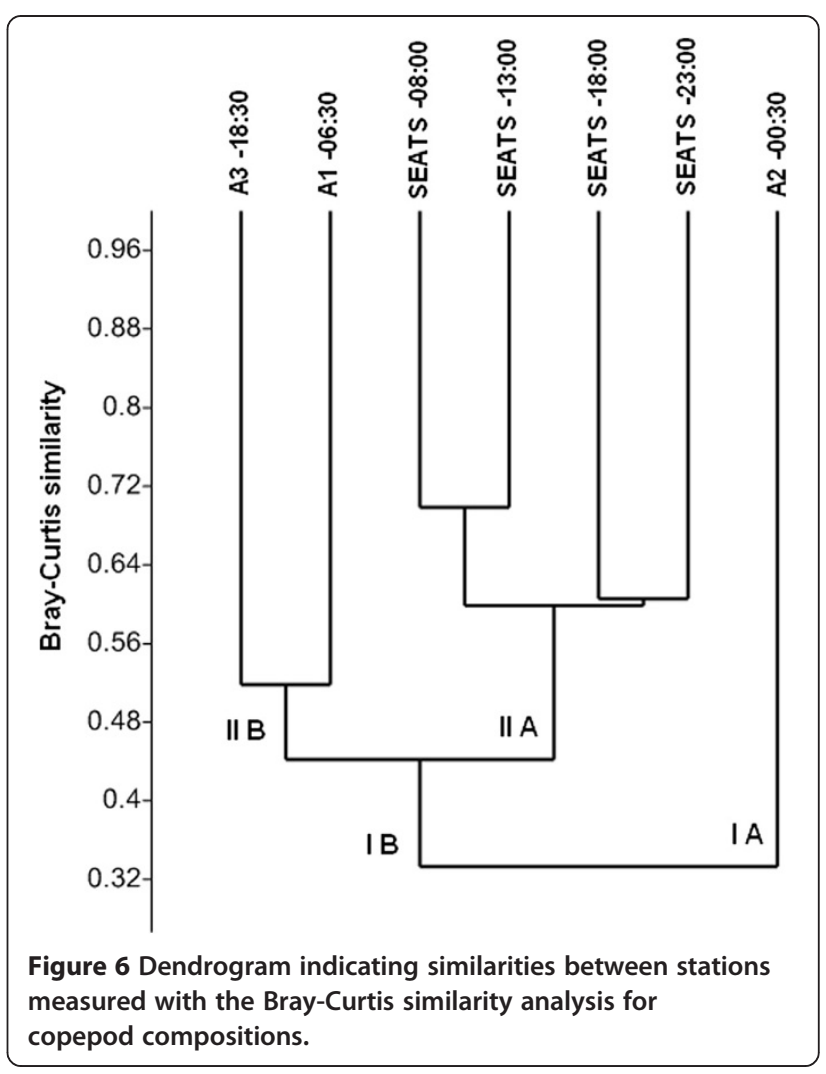

Table 4 Indicator species and index values (\%) for each cluster identified by analysis in Figure 6

\begin{tabular}{lccc}
\hline & \multicolumn{3}{c}{ Cluster level } \\
\cline { 2 - 4 } & IA & IIA & IIB \\
\hline Indicator species & & 11.60 & 24.12 \\
Acartia (Acartia) negligens & 5.80 & & \\
Cosmocalanus darwini & 20.29 & & \\
Nannocalanus minor & & & 6.76 \\
Calocalanus spp. & & & 5.81 \\
Paracandacia truncate & & 16.03 & 17.08 \\
Clausocalanus arcuicornis & & 10.67 & \\
Clausocalanus mastigophorus & & 6.41 & \\
Subeucalanus subtenuis & & & \\
Lucicutia flavicornis & 18.84 & 3.81 & \\
Pleuromamma gracilis & 36.23 & & \\
Paracalanus spp. & & & \\
Oithona spp. & & & \\
Corycaeus (Farranula) gibbula & & 13.13 & \\
Oncaea mediterranea & & & \\
Cumulative contribution & & 6.98 .02 & 75.81 \\
\hline
\end{tabular}




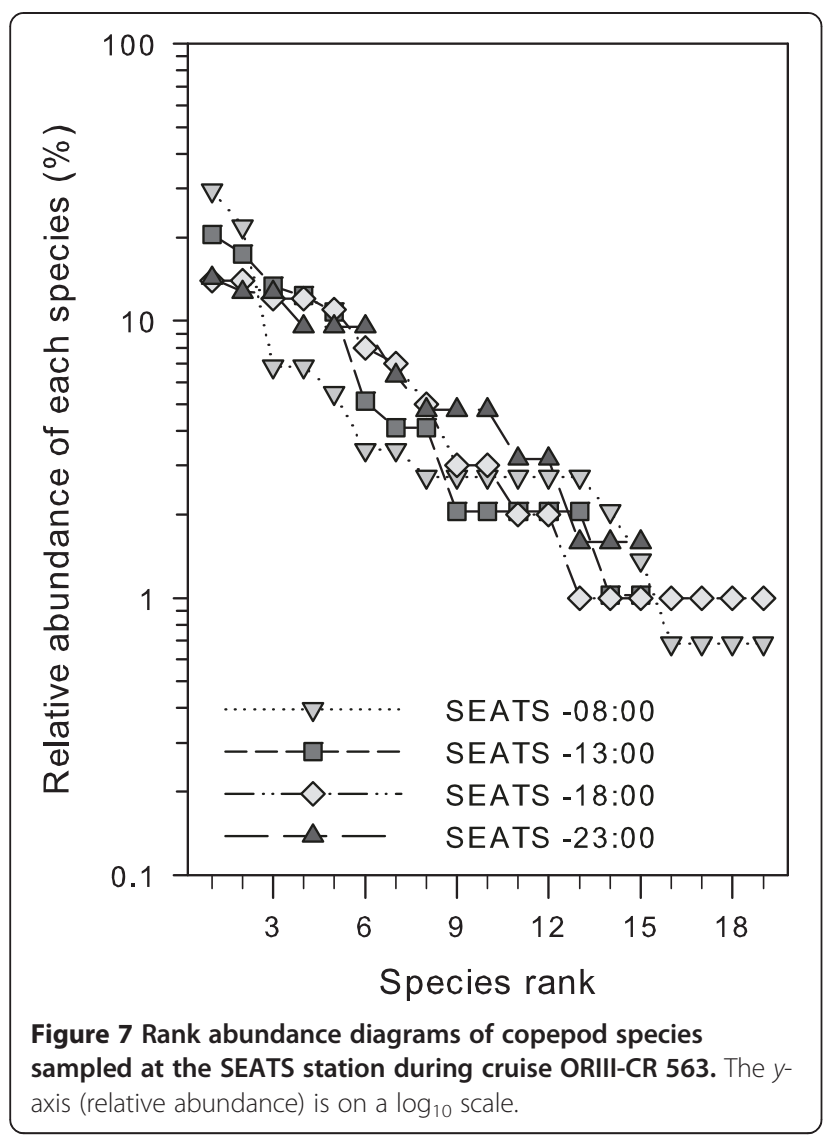

present study found calanoid copepods to be the most abundant taxa in waters shallower than $100 \mathrm{~m}$ in the northern SCS. These results confirm copepods as the dominant mesozooplankton taxon in coastal areas of the SCS, the Pearl River estuary (Tan et al. 2004), and the Malacca Strait (Yoshida et al. 2006).

Tseng et al. (2012b) reported that Noctilucales were the dominant zooplankton group (RA of $42.55 \%$ ) in surface waters of the northern SCS. A similar result was reported

Table 5 Copepod species only identified at SEATS station and abundances during the autumn 1999 sampling period

\begin{tabular}{lc}
\hline Copepod species & Mean \pm SD (ind./ $\mathbf{m}^{\mathbf{3}}$ ) \\
\hline Undinula vulgaris & $2.02 \pm 2.12$ \\
Pareucalanus attenuatus & $0.7 \pm 0.96$ \\
Euchaeta indica & $0.13 \pm 0.26$ \\
Acrocalanus gracilis & $0.43 \pm 0.56$ \\
Temora turbinata & $0.13 \pm 0.26$ \\
Oithona spp. & $6.47 \pm 11.62$ \\
Microsetella norvegica & $0.94 \pm 1.87$ \\
Corycaeus spp. & $0.19 \pm 0.38$ \\
Corycaeus (Farranula) concinna & $0.19 \pm 0.38$ \\
Oncaea spp. & $0.19 \pm 0.38$ \\
\hline
\end{tabular}

for Noctiluca scintillans (Macartney) Kofoid \& Swezy, 1921 , which was abundant $\left(7310.39 \pm 36,102.05\right.$ ind. $/ \mathrm{m}^{3}$, RA of $51.04 \%$ ) in surface waters of the southwestern East China Sea (ECS) during a summer cruise (Tseng et al. 2011b). The present study recorded Noctilucales (RA of $23.79 \%$ ) as the second most abundant taxon of zooplankton in waters above $100 \mathrm{~m}$ in depth. Sampling depths among these studies varied. Light quality and nutrients are important factors which affect the growth of Noctilucales (Stoeck 1999; Tseng et al. 2008f, 2011b). The quantity of irradiance in the surface zone was highest, and it decreased with increasing depth in the northern SCS (Wang et al. 2008). Vertical migrations of zooplankton also affect the abundance and community structure (Takahashi and Hirakawa 2001; Lo et al. 2004c; Liu et al. 2003; Silva et al. 2009) by changing the proportion of each taxon within the zooplankton community. Thus, densities and RA values of Noctilucales are higher in surface waters than in deeper layers.

\section{Copepod community structure}

Previous studies found a common trend of the copepod distribution in the SCS of the total abundances decreasing with an increasing sampling depth (Hwang et al. 2007a, 2010; Tseng et al. 2008a), similar to that reported off southern Brazil (Dias et al. 2010). The present study recorded an average abundance in waters shallower than $100 \mathrm{~m}$ of $99.14 \pm 97.84 \mathrm{ind} . / \mathrm{m}^{3}$. This value is lower than that in Tseng et al. (2012b) who recorded an average copepod abundance of $523.42 \pm 262.82 \mathrm{ind} . / \mathrm{m}^{3}$ in surface waters of the northern SCS. Previous studies in the SCS reported that the dominant copepod species varied. The dominant species in the present study were $P$. gracilis, $N$. minor, and L. flavicornis. Tseng et al. (2008a) reported that Clausocalanus furcatus, C. arcuicornis, and Paracalanus nanus were dominant at depths above $300 \mathrm{~m}$. In a similar investigation area, Tseng et al. (2012b) found that Paracalanus, Calocalanus, and Oncaea were the three predominant copepod genera in surface waters of the northern SCS. Hwang et al. (2007a) found that dominant species and copepod compositions changed with the sampling depth. Their results established that several species only appeared at specific depths. The present results indicated that the copepod species composition in the SCS varies with the sampling site, sampling season, and spatial scale of sampling.

Hwang et al. (2007b, 2010) discussed the distribution of Oithona spp. at different temporal and spatial scales. Their results demonstrated that copepods of Oithona spp. are commonly lost through larger mesh sizes. Both Hwang et al. (2007b) and the present study used nets with a $333-\mu \mathrm{m}$ mesh size. In the present study, we recorded an abundance of all Oithona spp. of $3.7 \pm 8.92$ ind. $/ \mathrm{m}^{3}$. This value of total Oithona spp. is very close to that reported by 
Hwang et al. (2007b) of $3.02 \pm 6.42 \mathrm{ind} . / \mathrm{m}^{3}$. In addition, Tseng et al. (2011a) stated that densities of smaller zooplankton were highly underestimated by larger-meshed nets. Our data confirmed that the 333- $\mu$ m mesh size used to collect Oithona copepod resulted in its low abundance in the northern SCS.

In the present study, $T$. turbinata was only recorded at the SEATS station and then rarely $\left(0.13 \pm 0.26\right.$ ind. $\left./ \mathrm{m}^{3}\right)$. In coastal areas of Taiwan, T. turbinata is dominant with high abundances and can be used as an indicator species for warm water in northern Taiwan (Hwang et al. 2004, 2006, 2009; Tseng et al. 2011c). A few previous reports found high abundance records that varied in different coastal regions, such as $187,672.11 \pm 819,416.82$ ind. $/ 1,000 \mathrm{~m}^{3}$ in waters adjacent to nuclear power plants (Hwang et al. 2004), 2,476 $\pm 15,208$ ind./100 $\mathrm{m}^{3}$ in Tapong Bay (Lo et al. 2004a), $136,333 \pm 355,493$ ind./1,000 $\mathrm{m}^{3}$ in an estuarine area of the Danshuei River (Hwang et al. 2006), $426 \pm 132$ ind. $/ \mathrm{m}^{3}$ in a eutrophic lagoon (Hsu et al. 2008), $540.79 \pm$ $508.87 \mathrm{ind} . / \mathrm{m}^{3}$ in an outfall area (Tseng et al. 2008e), and $192.05 \pm 58.93$ ind. $/ \mathrm{m}^{3}$ in coastal areas of northern Taiwan (Tseng et al. 2011c). This species also showed a high tolerance towards outfall containing pollutants in southwestern Taiwan (Tseng et al. 2008e) and outfall waters in northern Taiwan (Fang et al. 2006). In reports related to the SCS, abundances of T. turbinata were dramatically lower. Some results coincided with the present study of showing low densities. For example, Hwang et al. (2007a) did not find $T$. turbinata in the northern SCS. Tseng et al. (2008a) recorded $1.43 \pm 4.94$ ind. $/ \mathrm{m}^{3}$ in the northern SCS. Chang et al. (2010) reported low abundances $\left(0.1 \pm 0.4 \mathrm{ind} . / \mathrm{m}^{3}\right.$ in April and $6.4 \pm 9.3$ ind. $/ \mathrm{m}^{3}$ in September) in embayment environments of southern Taiwan in the northern SCS. Tseng et al. (2012b) reported $2.38 \pm 3.95 \mathrm{ind} . / \mathrm{m}^{3}$ in the northern SCS. Previous and present study results considered that T. turbinata belongs to a group of warm water species; it is dominant in coastal areas of Taiwan but is rarely found in the northern SCS.

Many studies suggested that copepod assemblages can be affected by several different factors, such as sampling depth (Hwang et al. 2007b, 2010; Tseng et al. 2008a), sampling time (Hwang et al. 2004, 2006, 2009; Tseng et al. 2008a; Chou et al. 2012), vertical migration (Lo et al. 2004c), mesh-size effects (Hwang et al. 2007b; Antacli et al. 2010; Tseng et al. 2011a), interplay/mixed waters (Tseng et al. 2012c), and spatiotemporal variations (Etilé et al. 2012). The present study confirmed that sampling depth is an important factor that influences the community structure of copepods in the northern SCS.

\section{Geospatial variability}

Hwang et al. (2007a) stated that copepod assemblages in the northern SCS were strongly affected by waters intruding from the $\mathrm{KC}$ in October. Their results showed that the composition of copepod assemblages changed with geospatial differences in longitude and latitude. Tseng et al. (2008a) reported that compositions of copepods in the northern SCS clearly differed between stations located in coastal areas and those offshore. Similar reports are available from areas outside the SCS, where copepod communities (Tseng et al. 2008f) and zooplankton in general (Tseng et al. 2011b) showed different patterns between the western and southern ECS during summer. In northeastern Taiwan, Kâ and Hwang (2011) reported on the distribution and composition of mesozooplankton which showed geospatial variations caused by the interplay/mixing of different water masses. From our T-S curves (Figure 3 ), we concluded that stations A1 and $\mathrm{A} 2$ were located in regions where water masses intruded from the $\mathrm{KC}$, while the SEATS station belonged to waters of the SCS. The proportion of zooplankton and composition of copepods in the present study indicated that the $\mathrm{KC}$ can shape plankton assemblages. The present results found significant geospatial variability in the compositions and structures of zooplankton and planktonic copepods among sampling stations. Our results also confirmed results of Hwang et al. (2007a), who reported that $\mathrm{KC}$ water changed copepod compositions in the northern SCS. Previous reports demonstrated that assemblages of marine zooplankton are affected by several factors, including salinity changes due to river discharges (Tan et al. 2004; Tseng et al. 2008a, 2011b), changes in water masses due to urban runoff (Tseng et al. 2008b,e), seasonal monsoon effects (Yoshida et al. 2006), and characteristics of water masses (Tseng et al. 2011b). The present study revealed that changes in zooplankton composition and copepod assemblages were related to depth and varied geospatially in the northern SCS. Furthermore, the present study recognized that the influence of water intruding from the $\mathrm{KC}$ could affect the surface layer down to $100 \mathrm{~m}$ in depth.

\section{Conclusions}

In conclusion, we provide three main results: (1) copepod species identified at the SEATS station were similar to those of previous reports which focused on the northern SCS; (2) the compositions and distributions of particular zooplankton taxa and copepods show geospatial variability in the northern SCS; and (3) abundances of zooplankton and copepods were lower in the water layer above $100 \mathrm{~m}$ in depth than in the layer above $5 \mathrm{~m}$.

\section{Competing interests}

The authors declare that they have no competing interests.

\section{Authors' contributions}

JSH designed the experiment and carried out the zooplankton sampling in the South China Sea cruise with LCT. QCC completed the taxonomic work of zooplankton and copepod species. LCT analyzed the data as well as made 
figures and tables. LCT, HUD, and JSH finalized the manuscript. All authors read and approved the final manuscript.

\section{Acknowledgments}

We are grateful for the financial support from the National Science Council, Taiwan, via projects NSC95-2621-B-019-005, NSC95-2611-M-019-003, NSC962611-M-019-0006, NSC97-2611-M-019-004, and CMBB-97529002A9 for JS Hwang. This work was supported by the National Research Foundation of Korea Grant funded by the Korean Government (MEST) (NRF-2010-0025412) for HU Dahms. We are thankful to Herbert Nyberg whose comments and suggestions substantially improved the manuscript. We acknowledge the assistance provided by the captain and crew of the Ocean Research Vessel III. We thank SC Wong and CZ Chen for the technical help during the sampling campaign.

\section{Author details}

${ }^{1}$ Institute of Marine Biology, National Taiwan Ocean University, 2 Pei-Ning Road, Keelung 20224, Taiwan. ${ }^{2}$ Green Life Science Department, College of Convergence, Sangmyung University, Seoul 110-743, South Korea. ${ }^{3}$ South China Sea Institute of Oceanology, Chinese Academy of Sciences, Guangzhou 510301, China.

\section{Received: 16 October 2012 Accepted: 7 January 2013}

\section{Published: 30 July 2013}

\section{References}

Antacli JC, Hernández D, Sabatini ME (2010) Estimating copepods' abundance with paired nets: implications of mesh size for population studies. I Sea Res 63:71-77

Box GEP, Cox DR (1964) An analysis of transformations with discussion. J Roy Stat Soc Ser B 26:211-246

Chang WB, Tseng LC, Dahms HU (2010) Abundance, distribution and community structure of planktonic copepods in surface waters of a semi-enclosed embayment of Taiwan during monsoon transition. Zool Stud 49:735-748

Chen QC (1992) Zooplankton of China seas, vol 1. Science Press, Beijing

Chen QC, Shen CJ (1974) The pelagic copepods of the South China Sea II. Stud Mar Sin 9:125-137 [in Chinese, with English abstract]

Chen QC, Zhang SZ (1965) The planktonic copepods of the yellow Sea and the East China Sea. I. Calanoida. Stud Mar Sin 7:20-131, 53 plates. [in Chinese, with English summary]

Chen QC, Zhang SZ, Zhu CS (1974) On planktonic copepods of the yellow Sea and the East China Sea. II. Cyclopoida and Harpacticoida. Stud Mar Sin 9:27-76, 24 plates. [in Chinese, with English summary]

Chen MR, Kâ S, Hwang JS (2010) Diet of the copepod Calanus sinicus Brodsky, 1962 (Copepoda, Calanoida, Calanidae) in northern coastal waters of Taiwan during the northeast monsoon period. Crustaceana 83:851-864

Chou C, Tseng LC, Ou CH, Chen QC, Hwang JS (2012) Seasonal succession of planktonic copepods in bight environments of north-eastern Taiwan. Zool Stud, 51:1380-1396

Dahms HU, Tseng LC, Hsiao SH, Chen CC, Kim BR, Hwang JS (2012) Biodiversity of planktonic copepods in the Lanyang River (NW Taiwan) - a typical watershed of Oceania. Zool Stud 51:160-174

Dias CO, Araujo AV, Paranhos R, Bonecker SLC (2010) Vertical copepod assemblages (0-2300 m) off southern Brazil. Zool Stud 49:230-242

Ding Y, Li C, Liu Y (2004) Overview of the South China Sea monsoon experiment. Adv Atmosph Sci 21:343-360

Dufrêne M, Legendre P (1997) Species assemblages and indicator species: the need for a flexible asymmetrical approach. Ecol Monogr 67:345-366

Dur G, Hwang JS, Souissi S, Tseng LC, Wu CH, Hsiao SH, Chen QC (2007) An overview of the influence of hydrodynamics on the spatial and temporal patterns of calanoid copepod communities around Taiwan. J Plankton Res 29:i97-i116

Etilé RN, Aka MN, Kouassi AM, Pagano M, N'Douba V (2012) Spatiotemporal variations in the abundance, biomass, fecundity, and production of Oithona brevicornis (Copepoda: Cyclopoida) in a West African tropical coastal lagoon (Grand-Lahou, Côte d'Ivoire). Zool Stud 51:627-643

Fang TH, Hwang JS, Hsiao SH, Chen HY (2006) Trace metals in seawater and copepods in the ocean outfall area off the northern Taiwan coast. Mar Environ Res 61:224-243

Hammer $\varnothing$, Harper DAT, Ryan PD (2001) PAST: Paleontological statistics software package for education and data analysis. Palaeontol Electron 4:9
Hsiao SH, Fang TH, C-t S, Hwang JS (2011) Effects of the Kuroshio Current on copepod assemblages in Taiwan. Zool Stud 50:475-490

Hsu PK, Lo WT, Shih CT (2008) The coupling of copepod assemblages and hydrography in a eutrophic lagoon in Taiwan: seasonal and spatial variations. Zool Stud 47:172-184

Hwang JS, Martens K (2011) Preface of zooplankton behavior and ecology, Proceedings of the conference on "Zooplankton behavior, ecology and aquaculture". Hydrobiologia 666:179

Hwang JS, Chen QC, Lo WT, Chen MP (2000a) Taxonomic composition and abundance of the copepods in the northern South China Sea. J Taiwan Mus 10:101-108

Hwang JS, Wang CH, Chan TY (2000b) Proceedings of the international symposium on marine biology in Taiwan - crustacean and zooplankton taxonomy, ecology and living resources. Natl Taiwan Mus Spec Publ Ser 10:1-200

Hwang JS, Chen QC, Wong CK (2003) Taxonomic composition, density and biomass of free-living copepods in the coastal waters of south-western Taiwan. Crustaceana 76:193-206

Hwang JS, Tu YY, Tseng LC, Fang LS, Souissi S, Fang TH, Lo WT, Twan WH, Hsiao SH, Wu CH, Peng SH, Wei TP, Chen QC (2004) Taxonomic composition and seasonal distribution of copepod assemblages from waters adjacent to nuclear power plant I and II in northern Taiwan. J Mar Sci Technol 12:380-391

Hwang JS, Souissi S, Tseng LC, Seuront L, Schmitt FG, Fang LS, Peng SH, Wu CH, Hsiao SH, Twan WH, Wei TP, Kumar R, Fang TH, Chen QC, Wong CK (2006) A 5-year study of the influence of the northeast and southwest monsoons on copepod assemblages in the boundary coastal waters between the East China Sea and the Taiwan Strait. J Plankton Res 28:943-958

Hwang JS, Dahms HU, Tseng LC, Chen QC (2007a) Intrusions of the Kuroshio Current in the northern South China Sea affect copepod assemblages of the Luzon strait. J Exp Mar Biol Ecol 352:12-27

Hwang JS, Kumar R, Dahms HU, Tseng LC, Chen QC (2007b) Mesh size affects abundance estimates of Oithona spp. (Copepoda: Cyclopoida). Crustaceana 80:827-837

Hwang JS, Souissi S, Dahms HU, Tseng LC, Schmitt FG, Chen QC (2009) Rankabundance allocations as a tool to analyze planktonic copepod assemblages off the Danshuei estuary (Taiwan). Zool Stud 48:49-62

Hwang JS, Kumar R, Dahms HU, Tseng LC, Chen QC (2010) Interannual, seasonal, and diurnal variation in vertical and horizontal distribution patterns of 6 Oithona spp. (Copepoda: Cyclopoida) in the South China Sea. Zool Stud 49:220-229

Irigoien X, Harris RP, Verheye HM, Joly P, Runge J, Starr M, Pond D, Campbell R, Shreeve R, Ward P, Smith AN, Dam HG, Peterson W, Tirelli V, Koski M, Smith T, Harbour D, Davidson R (2002) Copepod hatching success in marine ecosystems with high diatom concentrations. Nature 419:387-389

Kâ S, Hwang JS (2011) Mesozooplankton distribution and composition on the north-eastern coast of Taiwan during autumn: effects of the Kuroshio Current and hydrothermal vents. Zool Stud 50:155-163

Li W, Luo C, Wang D, Lei T (2010) Diurnal variations of precipitation over the South China Sea. Meteorol Atmos Phys 109:33-46

Liu SH, Sun S, Han BP (2003) Diel vertical migration of zooplankton following optimal food intake under predation. J Plankton Res 25:1069-1077

Lo WT, Hwang JS, Chen QC (2001) Identity and abundance of surface dwelling, coastal copepods of south-western Taiwan. Crustaceana 74:1139-1157

Lo WT, Chung CL, Shih CT (2004a) Seasonal distribution of copepods in the Tapong Bay, south-western Taiwan. Zool Stud 43:464-474

Lo WT, Hwang JS, Chen QC (2004b) Spatial variations of copepods in the surface waters of south-eastern Taiwan Strait. Zool Stud 43:218-228

Lo WT, Shih CT, Hwang JS (2004c) Diel vertical migration of the planktonic copepods at an upwelling station north of Taiwan, western North Pacific. J Plankton Res 26:89-97

Morton B, Blackmore G (2001) South China Sea. Mar Pollut Bull 42:1236-1263

Pauly D, Christensen V (1993) Stratified models of large marine ecosystems: a general approach and an application to the South China Sea. In: Sherman K, Alexander LM, Gold BD (eds) Large marine ecosystems: stress, mitigation, and sustainability. AAAS Press, Washington, DC, pp 148-174

Sanoamuang LO, Hwang JS (2011) Preface of Copepoda: biology and ecology, Proceedings of 10th International Conference on Copepoda. Hydrobiologia 666:1

Silva AMA, Medeiros PR, Silva MCBC, Barbosa JEL (2009) Diel vertical migration and distribution of zooplankton in a tropical Brazilian reservoir. Biotemas 22:49-57

Stoeck DK (1999) Mixotrophy among dinoflagellates. J Eukaryot Microbiol 46:397-401 
Takahashi T, Hirakawa K (2001) Day-night vertical distributions of the winter and spring copepod assemblages in Toyama Bay, southern Japan Sea, with special reference to Metridia pacifica and Oithona atlantica. Bull Plankton Soc Jap 48:1-13

Tan Y, Huang L, Chen Q, Huang X (2004) Seasonal variation in zooplankton composition and grazing impact on phytoplankton standing stock in the Pearl River Estuary. China Cont Shelf Res 24:1949-1968

Tseng LC, Dahms HU, Chen QC, Hwang JS (2008a) Copepod assemblages of the northern South China Sea. Crustaceana 81:1-22

Tseng LC, Kumar R, Dahms HU, Chen CT, Chen QC, Hwang JS (2008b) Epipelagic mesozooplankton succession and community structure above a marine outfall in the north-eastern South China Sea. J Environ Biol 29:275-280

Tseng LC, Kumar R, Dahms HU, Chen QC, Hwang JS (2008c) Monsoon driven seasonal succession of copepod assemblages in the coastal waters of the north-eastern Taiwan Strait. Zool Stud 47:46-60

Tseng LC, Kumar R, Dahms HU, Chen QC, Hwang JS (2008d) Copepod gut contents, ingestion rates and feeding impact in relation to their size structure in the south-eastern Taiwan Strait. Zool Stud 47:402-416

Tseng LC, Kumar R, Dahms HU, Chen CT, Souissi S, Chen QC, Hwang JS (2008e) Copepod community structure over a marine outfall area in the northeastern South China Sea. J Mar Biol Assoc UK 88:955-966

Tseng LC, Souissi S, Dahms HU, Chen QC, Hwang JS (2008f) Copepod communities related to water masses in the southwest East China Sea. Helg Mar Res 62:153-165

Tseng LC, Dahms HU, Chen QC, Hwang JS (2009) Copepod feeding study in the upper layer of the tropical South China Sea. Helg Mar Res 63:327-337

Tseng LC, Dahms HU, Hung JJ, Chen QC, Hwang JS (2011a) Can different mesh sizes affect the results of copepod community studies? J Exp Mar Biol Ecol 398:47-55

Tseng LC, Kumar R, Chen QC, Hwang JS (2011b) Summer distribution of Noctiluca scintillans and mesozooplankton in the western and southern East China Sea prior to the Three Gorges Dam operation. Hydrobiologia 666:239-256

Tseng LC, Kumar R, Chen QC, Hwang JS (2011C) Faunal shift between two copepod congeners (Temora discaudata and T. turbinata) in the vicinity of two nuclear power plants in southern East China Sea: spatiotemporal patterns of population trajectories over a decade. Hydrobiologia 666:301-315

Tseng LC, Dahms HU, Chen QC, Hwang JS (2012a) Mesozooplankton and copepod community structures in the southern East China Sea: the status during the monsoonal transition period in September. Helg Mar Res 66:621-634

Tseng LC, Dahms HU, Kumar R, Chen QC, Hwang JS (2012b) Autumn community structure in the shallow mixed layer of the subtropical South China Sea reveals a peculiar copepod and zooplankton assemblage. J Nat Hist 47:667-683

Tseng LC, Hung JJ, Chen QC, Hwang JS (2012C) Seasonality of the copepod assemblages associated with interplay waters off north-eastern Taiwan. Helg Mar Res. doi:10.1007/s10152-012-0339-7

Vandromme P, Schmitt FG, Souissi S, Buskey EJ, Strickler JR, Wu CH, Hwang JS (2010) Symbolic analysis of plankton swimming trajectories: case study of Strobilidium sp. (Protista) helical walk under various food conditions. Zool Stud 49:289-303

Wang G, Cao W, Yang D, Xu D (2008) Variation in down welling diffuse attenuation coefficient in the northern South China Sea. Chin J Oceanol Limnol 26:323-333

Wu CH, Dahms HU, Buskey EJ, Strickler JR, Hwang JS (2010) Behavioral interactions of Temora turbinata with potential ciliate prey. Zool Stud 49:157-168

Wu CH, Dahms HU, Cheng SH, Hwang JS (2011) Effects of food and light on naupliar swimming behavior of Apocyclops royi and Pseudodiaptomus annandalei (Crustacea, Copepoda). Hydrobiologia 666:167-178

Yoshida T, Toda T, Yusoff FM, Othman BHR (2006) Seasonal variation in zooplankton community in the coastal waters of the Straits of Malacca. Coast Mar Sci 30:320-327

doi:10.1186/1810-522X-52-2

Cite this article as: Tseng et al:: Geospatial variability in the autumn community structure of epipelagic zooplankton in the upper layer of the northern South China Sea. Zoological Studies 2013 52:2.

\section{Submit your manuscript to a SpringerOpen ${ }^{\circ}$ journal and benefit from:}

- Convenient online submission

- Rigorous peer review

- Immediate publication on acceptance

- Open access: articles freely available online

- High visibility within the field

- Retaining the copyright to your article

Submit your next manuscript at $\gg$ springeropen.com 